\title{
HUBUNGAN MOTIVASI BELAJAR SISWA DENGAN HASIL BELAJAR BIOLOGI PADA MATERI POKOK SISTEM EKSKRESI MANUSIA KELAS XI MIA SMA NEGERI 16 MEDAN
}

\author{
Inne Leomora Agnes Sinaga ${ }^{1 *}$, Masdiana Sinambela ${ }^{2}$, Rosida $^{3}$ \\ ${ }^{\mathbf{1 , 2}}$ Program Studi Pendidikan Biologi, FMIPA, Universitas Negeri Medan, Medan Jl. Willem Iskandar Psr. V \\ Medan Estate, Medan, Indonesia, 20221 \\ ${ }^{3}$ SMA Negeri 16 Medan, Jl Kapten Rahmad Buddin Kel. Terjun Kec. Medan Marelan, Medan, \\ Indonesia, 20256 \\ *E-mail : innesinaga3@gmail.com
}

\begin{abstract}
ABSTRAK
Program Penelitian ini bertujuan untuk mengetahui Hubungan Motivasi Belajar Siswa dengan Hasil Belajar Biologi pada Materi Pokok Sistem Ekskresi Manusia Kelas XI MIA SMA Negeri 16 Medan Tahun Pembelajaran 2016/2017. Populasi dalam penelitian ini adalah seluruh siswa XI MIA SMA Negeri 16 Medan yang berjumlah 152orang dan sampel penelitian ini adalah seluruh kelas XI MIA yang berjumlah 152 orang dengan cara teknik sempling total. Pengumpulan data yang digunakan adalah dengan menggunakan angket berstruktur dengan 4 option sebanyak 25 butir dan tes dengan 5 option sebanyak 25 soal. Teknik analisa yang digunakan adalah korelasi produk moment. Dari hasil perhitungan diperoleh $r_{\text {hitung }}=0,47$ dan indeks determinasi $(I)=22 \%$, yang berarti terdapat hubungan yang positif antara motivasi belajar siswa dengan hasil belajar biologi pada materi pokok sistem ekskresi manusia di kelas XI MIA SMA negeri 16 Medan tahun pembelajaran 2016/2017. Dari pengujian hipotesis diperoleh $t_{\text {hitung }}=6,56$, sedangkan $t_{\text {tabel }}=1,98$, berarti $t_{\text {hitung }}>$ $t_{\text {tabel }}(6.56>1,98)$ pada taraf signifikan $5 \%$ atau alpha 0,05 . Jadi dapat disimpulkan bahwa hipotesis alternatif yang menyatakan ada hubungan yang positif dan signifikan antara motivasi belajar siswa dengan hasil belajar biologi pada materi pokok sistem ekskresi manusia kelas XI MIA SMA negeri 16 Medan tahun pembelajaran 2016/2017 dapat diterima.
\end{abstract}

Kata Kunci : Motivasi Belajar, Hasil Belajar Biologi, Materi Pokok Sistem Ekskresi Manusia

\section{ABSTRACT}

This research aim to to know Relation Motivation Learn Student with Result Learn Biology in Material of System Human's Excretion Class XI MIA Sma Negeri 16 Medan Academic Year 2016/2017. Population in this research is all student XI MIA SMA Negeri 16 Field amounting to 152 and people of sampel taken all student XI MIA 152 people by ethnic sampling total. Technique data collecting the used by using enquette have structure to by 4 option counted 25 and item of tes by 5 option counted 25 problem. Analysis technique the used is product correlation of moment. From result of calculation obtained by $r_{\text {hitung }}=0,47$ and index of determination $(I)=22 \%$ that mean there are relation which are positive between motivation learn student with result learn biology in material of system human's excretion class XI MIA SMA Negeri 16 Medan academic year $2016 / 2017$. From examination of hypothesis obtained by $t_{\text {hitung }}=6,56$, while $t_{\text {tabel }}=1,98$, meaning $t_{\text {hitung }}>t_{\text {tabel }}(6,56>1,98)$ at level of signifikan $5 \%$ or alpha 0,05 . Becoming can be concluded that alternative hypothesis expressing there is relation/link which are positive and signifikan between motivation learn student with result learn biology in material of system human's excretion class XI MIA SMA Negeri 16 Medan academicyear 2016/2017 can be accept.

Keywords :Motivation Lern, Result Learn Biology, Materials of System Human's Excretion.

\section{PENDAHULUAN}

Keberhasilan dan kegagalan proses belajar dipengaruhi oleh beberapa faktor yang secara garis besar dibagi menjadi faktor internal dan faktor eksternal. Faktor internal adalah semua faktor yang berasal dari dalam diri siswa itu sendiri yaitu fisiologi dan psikologi. Aspek fisiologi meliputi aspek yang berhubungan dengan kondisi fisik misalnya kesehatan dan aspek psikologi meliputi intelegensi, hak, sikap, bakat, minat, motivasi dan kesiapan. Faktor eksternal adalah faktor yang berasal dari luar diri siswa antara lain faktor keluarga, sekolah, dan faktor masyarakat.

Salah satu faktor yang sangat mempengaruhi tingkat hasil belajar siswa adalah motivasi belajar. Motivasi belajar dikatakan sebagai penggerak tingkah laku menuju suatu tujuan, didasari adanya suatu kebutuhan dan juga mempunyai peranan yang sangat penting dalam kegiatan belajar. Seorang akan berhasil belajar jika 
pada dirinya ada keinginan ataupun dorongan untuk belajar. Seseorang akan berhasil dalam belajar kalau pada dirinya ada keinginan atau dorongan untuk belajar. Inilah prinsip dan hukum pertama dalam kegiatan pendidikan dan pengajaran. Dalam motivasi terkandung adanya keinginan yang yang mengaktifkan, menggerakkan, menyalurkan, mengarahkan sikap dan perilaku individu belajar (Sardiman, 2010).

Motivasi sebagai faktor internal hasil belajar berfungsi menimbulkan, mendasari, mengarahkan perbuatan belajar. Motivasi dapat menentukan baik tidaknya dalam mencapai tujuan, sehingga semakin besar motivasinya akan semakin besar kesuksesan belajarnya. Seorang yang besar motivasinya akan giat berusaha, tampak gigih, dan tidak mudah menyerah. Dengan kata lain bahwa dengan adanya usaha yang tekun dan terutama didasari adanya motivasi, maka seseorang yang belajar itu akan melahirkan prestasi besar yang baik. Dalam kegiatan belajar motivasi sangat diperlukan, sebab seseorang yang yang tidak mempunyai motivasi dalam belajar, tidak akan mungkin dapat melakukan aktivitas belajar.

Biologi salah satu cabang IPA, masih sangat perlu dipelajari dan dikembangkan melalui pembinaan siswa/siswi dalam bidang studi biologi. Jadi tidak diragukan lagi bahwa biologi merupakan salah satu kekuatan utama pembentuk konsepsi tentang alam, serta hakekat dan tujuan manusia dalam kehidupan.

Dengan melihat begitu pentingnya biologi dalam kehidupan manusia terlebih dalam zaman teknologi saat ini, maka sudah sewajarnya generasi muda khususnya siswa/siswi baik dari tingkat SD sampai Perguruan Tinggi dibekali dengan penguasaan kemampuan biologi yang cukup untuk bisa mengikuti perkembangan teknologi saat ini. Kondisi di lapangan memperlihatkan tidak semua siswa/siswi menaruh perhatian dan keinginan terhadap pelajaran biologi, kondisi ini penulis temukan ketika melaksanakan program pengalaman lapangan (PPL). Tidak semua peserta didik menaruh perhatian terhadap pelajaran biologi karena beranggapan biologi itu sulit, membosankan dan kurang bermanfaat. Hal ini tentunya tidak kita harapkan karena dapat mempengaruhi hasil belajar. Hal yang sama juga penulis temukan di sekolah SMA Negeri 16 Medan yang penulis tetapkan sebagai tempat penelitian. Dimana, masih banyak siswa/siswi yang kurang meminati mata pelajaran biologi. Hal ini penulis ketahui, setelah penulis melihat rendahnya nilai ulangan harian dari siswa/siswi tersebut. Masih banyak yang memiliki nilai di bawah standar KKM yaitu di bawah 70 .
Bila siswa menyadari bahwa belajar merupakan satu alat untuk mencapai beberapa tujuan yang dianggapnya penting dan bila siswa melihat bahwa hasil dari pengalaman belajarnya akan membawa kemajuan bagi dirinya, kemungkinan besar ia akan termotivasi untuk mempelajarinya. Dari uraian diatas, kita ketahui bahwa motivasi memegang peranan penting dalam kegiatan belajar mengajar. Motivasi memegang peranan penting dalam memberikan gairah, semangat dan rasa senang dalam belajar, sehingga yang mempunyai motivasi yang tinggi mempunyai energi yang banyak untuk melaksanakan kegiatan belajar.

Berdasarkan penelitian sebelumnya, Sari (2013) menyatakan bahwa motivasi belajar mempunyai hubungan yang signifikan dengan hasil belajar siswa. Berdasarkan kontribusi motivasi terhadap hasil belajar siswa di SMP Negeri 1 Kranggaan Kecamatan Kranggaan Kabupaten Temanggung pada semester 1 tahun pembelajaran 2012/2013, yaitu sebesar 56,6\%. Afnizar (2007), hubungan motivasi terhadap hasil belajar siswa pada mata pelajaran biologi di kelas XI IPA diperoleh nilai rata - rata 7,7 dengan nilai tertinggi 8,0 dan terendah 6,2, dan Danar (2012) membuktikan bahwa terdapat hubungan positif dan signifikan antara motifasi belajar dengan hasil belajar siswa. Besar kontribusi motivasi dengan hasil belajar siswa kelas X SMK MA'ARIF WATES yaitu sebesar 59,3\%.

Keberhasilan siswa dapat ditentukan oleh motivasi belajar siswa yang dimilikinya. Dilihat darihasil korelasi yang positif dapat dinyatakan bahwa semakin tinggi motivasi belajar siswa makan akan semakin tinggi pula hasil belajar siswa. Begitu pula sebaliknya semakin rendah motivasi belajar siswa maka akan di ikuti hasil belajar yang rendah pula. Menurut Suviana (2012) menyatakan bahwa motivasi berhubungan secara positif dan signifikan terhadap hasil belajar. Aritonang (2010) juga menyatakan bahwa motivasi berhubungan dengan signifikan terhadap hasil belajar.

Tujuan penelitian ini adalah Untuk mengetahui hubungan antara motivasi belajar siswa dengan hasil belajar biologi pada materi pokok Sistem Ekskresi Manusia kelas XI MIA SMA Negeri 16 Medan T.P.2016/2017 dan Untuk mengetahui kontribusi motivasi belajar siswa dengan hasil belajar biologi pada materi pokok Sistem Ekskresi Manusia kelas XI MIA SMA Negeri 16 Medan T.P.2016/2017. Data hasil penelitian dapat dijadikan sebagai salah satu rujukan dalam pengembangan kurikulum kedepan, terkhusus Kurikulum 2013. 


\section{METODE PENELITIAN}

Penelitian ini dilaksanakan di SMA Negeri 16 Medan, Jl Kapten Rahmad Budin, Kecamatan Medan Marelan, Sumatera Utara. Penelitian ini telah dilaksanakan pada bulan Februari- Mei 2017. Populasi pada penelitian adalah seluruh siswa kelas XI MIA (XI 1-XI 4) SMA Negeri 16 Medan Tahun Pembelajaran 2016/2017 sebanyak 4 kelas, dengan masing-masing kelas terdiri dari 40 siswa atau jumlah seluruhnya terdiri dari 152 siswa. Cara pengambilan sampel dilakukan dengan cara total sampling, dimana yang diambil untuk dijadikan sampel adalah seluruh kelas XI MIA SMA Negeri 16 yang berjumlah 152 siswa. Jenis penelitian ini adalah deskriptif yang bersifat korelasional. Deskriptif yaitu penelitian yang menggambarkan objek penelitian berdasarkan fakta-fakta, dan bersifat korelasional berarti menjelaskan hubungan dari variabel yaitu mencari adanya hubungan ( $r$ ) antara variabel bebas (X) dengan variabel terikat $(\mathrm{Y})$, dan mencari kontribusi ( $R$ ) variabel bebas $(X)$ dengan variaabel terikat $(\mathrm{Y})$.

Dalam penelitian ini, peneliti menggunakan angket tertutup (angket berstruktur) yaitu angket yang disajikan dalam bentuk sedemikian rupa sehingga responden diminta untuk memilih satu jawaban yang sesuai dengan karakteristik dirinya. Untuk mendapatkan data motivasi belajar siswa digunakan instrument angket. Angket terdiri dari tipe memilih dengan cara membubuhkan tanda check $(v)$ dari salah satu pilihan jawaban yang diberikan dengan 25 item pertanyaan. Butir pertanyaan/pernyataan pada angket dijabarkan melalui indikator, angket ini diisi oleh siswa. Setiap item mempunyai 4 option jawaban. Bobot skor jawaban ditentukan berdasarkan skala likert, dengan nilai setiap option sebagai berikut: skor 4= Sangat Setuju, skor 3= Setuju, skor 2= Tidak Setuju, skor 1= Sangat Tidak Setuju. (Arikunto, 2013). Instrumen sebelum digunakan terlebih dahulu di validkan ke validator ahli.

Tabel 1. Kisi-kisi Angket Motivasi Belajar Siswa

\begin{tabular}{lcc}
\hline \multicolumn{1}{c}{ Indikator Motivasi } & Nomor Item & Jumlah \\
\hline A. Intrinsik (Siswa) & & 2 \\
Kebutuhan untuk diri sendiri (Aktualisasi diri) & 1,8 & 2 \\
Kebutuhan untuk menyenangkan hati orang lain & 6,7 & 2 \\
Kebutuhan untuk memperoleh pengetahuan & 2,3 & 2 \\
Untuk cita-cita & 4,5 & 2 \\
Ada hasrat untuk belajar & 9,10 & 2 \\
Minat & 11,12 & \\
B. Ekstrinsik (Guru) & & 1 \\
Memberi angka & 13 & 2 \\
Hadiah & 14,15 & 2 \\
Saingan/kompetisi & 16,17 & 2 \\
Memberi ulangan & 18,19 & 1 \\
Mengetahui hasil & 20 & 2 \\
Pujian & 21,22 & 2 \\
Hukuman & 23,24 & 1 \\
Tujuan & 25 & 25 \\
\hline Jumlah Soal & & \\
\hline
\end{tabular}

Instrumen yang digunakan untuk memperoleh data hasil belajar dilakukan tes hasil belajar pada materi sistem ekskresi manusia disusun dalam bentuk pilihan ganda sebanyak 40 soal dan terdiri dari 5 (lima) pilihan jawaban yang telah divalidasi. Soal disusun berdasarkan indikator dari RPP guru biologi yang mengajar di kelas XI MIA SMA
Negeri 16 Medan. Tes diberikan setelah pembelajaran materi sistem ekskresi manusia selesai. Dimana dalam menyusun soal disesuaikan dengan kemampuan berdasarkan taksonomi bloom yaitu: Pengetahuan, Pemahaman, Penerapan, Analisis, Evaluasi, dan Kreasi. 
Tabel 2. Kisi-Kisi Tes Hasil Belajar pada Materi Sistem Ekskresi Manusia

\begin{tabular}{|c|c|c|c|c|c|c|c|c|}
\hline \multirow{2}{*}{ No. } & \multirow{2}{*}{ Indikator } & \multicolumn{6}{|c|}{ Aspek Kognitif } & \multirow{2}{*}{ Jumlah } \\
\hline & & $\mathrm{C} 1$ & $\mathrm{C} 2$ & $\mathrm{C3}$ & $\mathrm{C} 4$ & $\mathrm{C} 5$ & C6 & \\
\hline 1. & $\begin{array}{l}\text { Membedakan pengertian ekskresi, } \\
\text { sekresi dan defekasi }\end{array}$ & $7 *, 31^{*}$ & 2 & & $21^{*}$ & $1 *$ & & 5 \\
\hline 2. & $\begin{array}{l}\text { Menjelaskan struktur ginjal dan } \\
\text { proses pembentukan urin }\end{array}$ & $\begin{array}{l}5,10^{\wedge} \\
24^{*} \\
38^{*}\end{array}$ & $\begin{array}{l}6 \\
37^{*}\end{array}$ & $\begin{array}{l}19 \\
23 * \\
40^{*}\end{array}$ & $13^{*}$ & & & 10 \\
\hline 3. & $\begin{array}{l}\text { Mendeskripsikan struktur dan } \\
\text { fungsi kulit sebagai alat ekskresi }\end{array}$ & $\begin{array}{l}12^{*} \\
26^{*}\end{array}$ & $30^{\wedge}$ & $33^{*}$ & $17^{*}$ & 3 & $25^{*}$ & 7 \\
\hline 4. & $\begin{array}{l}\text { Mendeskripsikan struktur dan } \\
\text { fungsi hati sebagai alat ekskresi }\end{array}$ & $\begin{array}{l}18 \\
20^{*} \\
34^{*}\end{array}$ & $\begin{array}{l}27 \\
32 *\end{array}$ & $9 *$ & $\begin{array}{l}4, \\
28 *\end{array}$ & & & 8 \\
\hline 5. & $\begin{array}{l}\text { Mendeskripsikan struktur dan } \\
\text { fungsi paru-paru sebagai alat } \\
\text { ekskresi }\end{array}$ & $\begin{array}{l}8^{\wedge} \\
16^{*}, 35\end{array}$ & $\begin{array}{l}11 \\
36^{*}\end{array}$ & & & & & 5 \\
\hline 6. & $\begin{array}{l}\text { Mengidentifikasi } \\
\text { penyakit/gangguan pada alat } \\
\text { ekskresi manusia }\end{array}$ & $14^{*}$ & $29 *$ & $\begin{array}{l}39 \\
22 *\end{array}$ & & & $15^{\wedge}$ & 5 \\
\hline & Jumlah & $16 / 10$ & $8 / 4$ & $8 / 5$ & $4 / 4$ & $2 / 1$ & $2 / 1$ & $40 / 25$ \\
\hline
\end{tabular}

* : Soal valid dan digunakan,

$\wedge$ : Soal valid tidak digunakan,

Soal tidak bertanda tidak valid

Uji instrumen penelitian dilakukan den uji validitas Arikunto (2013) mengatakan sebuah instrumen dapat dikatakan baik sebagai alat ukur harus memenuhi persyaratan, yaitu memiliki validitas. Validitas adalah suatu ukuran yang menunjukkan tingkat-tingkat kevalidan atau kesahihan suatu instrumen, sebuah instrumen dikatakan valid apabila mampu mengukur apa yang diinginkan, sebuah instrumen dikatakan valid apabila dapat mengungkapkan fakta dari variabel yang teliti secara tepat. Tinggi rendahnya validasi instrumen menunjukkan sejauh mana data terkumpul tidak menyimpang dari gambaran validasi yang dimaksud. Untuk arealisasi validasi digunakan rumus korelasi product moment. Kemudian dengan uji reabilitas agar tes dapat dipercaya jika memberikan hasil yang tetap walaupun diuji berulang kali selalu menunjukkan suatu ketepatan. Selanjutnya tingkat kesukaran soal, dimana soal yang baik adalah soal yang tidak terlalu mudah dan tidak terlalu sukar.Soal yang mudah tidak merangsang siswa untuk mempertinggi usaha untuk memecahkannya. Sebaliknya, soal yang terlalu sukar akan menyebabkan siswa menjadi putus asa dan tidak mempunyai semangat untuk mencoba lagi untuk mengerjakannya karena di luar jangkauan dan yang terakhir daya beda soal,. daya pembeda soal adalah kemampuan suatu soal untuk membedakan antara siswa yang berkemampuan tinggi dengan siswa yang berkemampuan
rendah.Angka yang menunjukkan besarnya daya pembeda disebut indeks dikriminasi, disingkat $D$.

Analisis data bertujuan untuk mengelola data yang diperoleh dari hasil penelitian, yang berguna untuk mempertanggungjawabkan kebenarannya. Mencari nilai rata-rata (mean), standart deviasi kemudian mencari perhitungan tingkat kecenderungan variabel penelitia untuk penafsiran tingkat kecenderungan skor masingmasing variabel dihitung dengan menggunakan ratarata (Xi) dan simpangan baku ideal (SDi) yang dikategorikan menjadi empat kelompok. (Arikunto, 2006).

Sebelum dilakukan pengukuran hipotesis terlebih dahulu dilakukan uji persyaratan analisis. Uji normalitas dilakukan untul memeriksa apakah data variabel penelitian berdistribusi normal atau tidak. Pengujian terhadap data berdistribusi normal atau tidak menggunakan uji Liliefors dengan taraf signifikan 5\% $(\alpha=0,05)$. Kriteria pengujiannya adalah menolak hipotesis jika $L_{0}$ yang diperoleh dari data pengamatan melebihi $\mathrm{L}$ dari daftar tabel $\left(L_{0}>L_{\text {tabel }}\right)$, sedangkan menerima hipotesis ketika $L_{0}$ yang diperoleh dari pengamatan kurang dari 1 dari daftar tabel atau $\mathrm{L}_{0}>\mathrm{L}_{\text {tabel }}$ (Sudjana,2009). Selanjutnya uji homogenitas dilakukan untuk mengetahui tingkat persamaan variabel dan $Y$ dengan uji Barlett. Adapun langkah-langkah uji Barlett menurut Sudjana (2009).

Uji Linieritas yang dilakukan dalam penelitian ini adalah dengan uji regresi linier 
sederhana $\mathrm{Y}$ atas $\mathrm{X}$ (regresi dimana $\mathrm{X}$ sebagai variabel bebasnya dan $Y$ sebagai variabel tidak bebas. Kemudian koefisien korelasi, dan untuk menguji besar korelasi antara variabel $X$ dan variabel $Y$ dilakukan dengan menggunakan rumus korelasi product momment dari Karl dan Koefisien Determinan atau Konstributor $\left(r^{2}\right)$. Untuk mengetahui apakah terdapat hubungan yang signifikan antara variabel $\mathrm{X}$ dan variabel $\mathrm{Y}$ maka diperlukan pengujian terhadap Hipotesis.

\section{HASIL PENELITIAN}

Berdasarkan hasil penelitian motivasi belajar dengan jumlah responden 152 orang diketahui skor tertinggi 92 dan skor terendah 62 dengan rata-rata 78,75 dan simpangan baku 6,84 . Untuk penafsiran tingkat kecenderungan variabel motivasi belajar siswa dapat dilihat pada Tabel 3 .

Tabel 3. Penafsiran Tingkat Kecenderungan Motivasi Belajar

\begin{tabular}{cccc}
\hline Kelompok & F.Absolut & F.Relatif & Kategori \\
\hline$>81,25$ & 49 & $32 \%$ & Tinggi \\
$>62,5-81,25$ & 97 & $64 \%$ & Cukup \\
$>43,75-62,5$ & 6 & $4 \%$ & Kurang \\
$<43,75$ & 0 & $0 \%$ & Rendah \\
\hline Jumlah & 152 & $100 \%$ & \\
\hline
\end{tabular}

Dari tabel diketahui bahwa ada 49 siswa (32\%) yang memiliki motivasi belajar dengan kategori tinggi, 97 siswa (64\%) memiliki motivasi belajar dengan kategori cukup, 6 siswa (4\%) dengan kategori kurang dan tidak ada siswa yang memiliki motivasi belajar dengan kategori rendah. Dari hasil perhitungan di atas maka dapat diketahui bahwa secara umum motivasi belajar siswa kelas XI MIA
SMA Negeri 16 Medan Tahun Pembelajaran 2016/2017 termasuk dalam kategori cukup.

Hasil belajar siswa diperoleh dari hasil tes yang berjumlah 25 soal. Untuk skor hasil belajar siswa diketahui skor tertinggi adalah 84 dan skor terendah adalah 44 dengan rata-rata 64,66 dan simpangan baku 12,38 . Untuk penafsiran tingkat kecenderungan skor variabel hasil belajar siswa dapat dilihat pada Tabel 4.

Tabel 4. Tingkat Kecenderungan Skor Hasil Belajar

\begin{tabular}{cccc}
\hline Kelompok & F.Absolut & F.Relatif & Kategori \\
\hline$>75,05$ & 43 & $28 \%$ & Tinggi \\
$>50-75,05$ & 89 & $59 \%$ & Cukup \\
$>24,9-50,0$ & 20 & $13 \%$ & Kurang \\
$<24,9$ & 0 & $0 \%$ & Rendah \\
\hline Jumlah & 152 & $100 \%$ &
\end{tabular}

Dari tabel 4.2. diketahui bahwa ada 43 siswa (28\%) yang memperoleh hasil belajar dengan kategori tinggi, 89 siswa (59\%) memperoleh hasil belajar dengan kategori cukup, 20 siswa (13\%) memperoleh hasil belajar dengan kategori kurang, dan tidak ada siswa yang memperoleh hasil belajar dengan kategori rendah. Dari hasil perhitungan di atas maka dapat diketahui bahwa secara umum perolehan hasil belajar siswa kelas XI MIA SMA Negeri 16 Medan Tahun Pembelajaran 2016/2017 termasuk kategori cukup.

Teknik yang digunakan untuk uji normalitas ini adalah uji liliefors. Setelah dilakukan perhitungan, diperoleh nilai kritis L yang tertera pada Tabel 5.

Tabel 5. Uji Normalitas

\begin{tabular}{llll}
\hline \multicolumn{1}{c}{ Instrumen } & \multicolumn{1}{c}{$\mathbf{L}_{\text {hitung }}$} & $\mathbf{L}_{\text {tabel }}(\boldsymbol{\alpha}=\mathbf{0 , 0 5})$ & Kategori \\
\hline Motivasi Belajar $(\mathrm{X})$ & 0.0702 & 0.0720 & Normal \\
Hasil Belajar $(\mathrm{Y})$ & 0.0643 & & Normal \\
\hline
\end{tabular}

Berdasarkan perhitungan yang telah dilakukan diketahui $L_{\text {hitung }}$ untuk data motivasi belajar dengan $\mathrm{n}=152$ adalah 0,0702. setelah dikonsultasikan dengan harga $L_{\text {tabel }}=0,0720$ diperoleh harga $L_{\text {hitung }}<L_{\text {tabel }}(0,0702<0,0720)$ sehingga dapat diketahui bahwa data motivasi berasal dari populasi yang berdistribusi normal. Untuk data hasil belajar siswa harga $L_{\text {hitung }}=0,0643$, setelah dikonsultasikan dengan harga $L_{\text {tabel }}$ diketahui bahwa $L_{\text {hitung }}<L_{\text {tabel }}(0,0643<0,0720)$, dengan 
demikian maka dapat diketahui bahwa data hasil belajar juga berasal dari populasi yang berdistribusi normal.

Untuk menguji homogenitas digunakan uji Barlett dengan statistik Chi-kuadrat. Dari perhitungan diperoleh $\chi_{\text {hitung }}^{2}=1,75$, sedangkan dari daftar distribusi Chi- kuadrat dengan $\mathrm{dk}=1$ didapat $\chi_{\text {tabel }}^{2}=3,84$. setelah harga $\chi_{\text {hitung }}^{2}$ dikonsultasikan dengan harga $\chi_{\text {tabel }}^{2}$ diperoleh hasil $\chi_{\text {hitung }}^{2}<\chi_{\text {tabel }}^{2}$ atau $(1,75<3,84)$. Dengan demikian dapat diketahui bahwa data motivasi dan data hasil belajar siswa memiliki varians yang seragam atau homogen.

Dari perhitungan yang telah dilakukan dengan uji linieritas dan keberartian regresi diketahui harga $a=28,41$ dan harga $b=0,85$. dari harga $a+b$ yang telah diperoleh diatas maka diketahui bahwa bentuk persamaan regresi $\mathrm{Y}$ atas $\mathrm{X}$ adalah : $\hat{Y}=28,41+0.85 x$. Untuk membuktikan apakah persamaan diatas merupakan regresi yang linier, maka harus memenuhi kriteria $F_{\text {hitung }}<F_{\text {tabel }}$ pada taraf signifikan $\alpha=0,05$.

Dari analisis data yang diperoleh bahwa Ftabel dk (20:130) pada $\alpha=0,05$ adalah 1,64 sedangkan Fhitung yang diperoleh adalah $-6,4804$. ternyata $F_{\text {hitung }}<F_{\text {tabel }}(-6,4804<1,64)$. Maka dapat disimpulkan bahwa persamaan regresi tersebut merupakan regresi yang linier. Berikut disajikan ringkasan analisis varians yang menguji kelineran dan keberartian persamaan regresi hasil belajar siswa dengan motivasi belajar.

Tabel 6. Ringkasan Anava Untuk Persamaan Regresi $\mathrm{Y}$ atas $\mathrm{X}$

\begin{tabular}{|c|c|c|c|c|}
\hline Sumber Variasi & Dk & JK & KT & $\mathrm{F}$ \\
\hline Total & 152 & 658608 & 658608 & \\
\hline Regresi(a) & 1 & 635457.79 & 635457.79 & \\
\hline Regresi (b/a) & 1 & 5111.05 & 5111,05 & 42,49 \\
\hline Residu & 150 & & 120,27 & \\
\hline Tuna Cocok & 20 & -5965922.11 & $-298296,10$ & \\
\hline Kekeliruan & 130 & 5983962,06 & 46030,48 & $-6,48$ \\
\hline
\end{tabular}

Perhitungan koefisien korelasi dilakukan dengan analisis korelasi product moment untuk uji dua pihak. Hipotesis alternatif $(\mathrm{Ha}: \rho \neq 0$ ) diterima apabila $-1 \leq r \leq+1 ; r \neq 0$ pada taraf signifikansi $5 \%$. Dari perhitungan yang telah dilakukan diketahui bahwa harga $r=0.47$ dan ini telah memenuhi kriteria $-1 \leq r \leq+1 ; r \neq 0 \quad(-1 \leq 0.47 \leq+1 r \neq 0)$, maka dapat disimpulkan bahwa hipotesis alternatif yang menyatakan terdapat korelasi yang positif antara variabel motivasi dengan hasil belajar siswa diterima. Dari hasil perhitungan koefisien korelasi diatas dapat diperoleh harga indeks determinasi (I) $=\left(r^{2}\right) \times 100 \%=22 \%$, yang berarti faktor motivasi memberikan kontribusi sebesar $22 \%$ terhadap hasil belajar siswa dan sisanya ditentukan oleh faktorfaktor yang lain.

Dari hasil uji statistik untuk uji hipotesis diperoleh $t_{\text {hitung }}$ sebesar 6,56. dari daftar distribusi dengan $\mathrm{dk}=150$ dan taraf signifikansi 5\% diperoleh $t_{\text {tabel }}=1,98$. Kriteria pengujian diterima Ha jika $t_{\text {hitung }}$ $>t_{\text {tabel }}$. Dari hasil perhitungan diperoleh $t_{\text {hitung }}>t_{\text {tabel }}$ $(5,60>1,98)$. Dengan demikian maka $\mathrm{Ha}: \rho \neq 0$ diterima sehingga dapat diketahui bahwa ada hubungan yang signifikan antara motivasi dengan hasil belajar siswa pada materi pokok sistem ekskresi di kelas XI MIA SMA Negeri 16 Medan Tahun Pembelajaran 2016/2017.

\section{PEMBAHASAN}

Dari hasil penelitian diperoleh bahwa motivasi belajar berhubungan positif dengan hasil belajar dan memberikan kontribusi terhadap peningkatan hasil belajar siswa SMA Negeri 16 Medan. Dapat dilihat dari motivasi siswa kelas XI MIA pada saat penelitian yaitu tingginya keaktifan dari siswanya dalam menyalurkan pendapat mereka dengan bertanya tentang pelajaran dan juga instrumen yang diberikan kepada mereka. Rasa ingin tahu yang besar, tertib dan semangat yang dimiliki oleh siswa dalam mengerjakannya instrumen tersebut membuktikan adanya dorongan dari dalam dirinya untuk memperoleh hasil yang baik atas apa yang mereka kerjakan. Hal ini dapat diketahui dari hasil angket dengan persentase $64 \%$ dengan jumlah 97 siswa memiliki motivasi belajar dengan kategori cukup.

Dibuktikan juga dari proses pengerjaan tes untuk memperoleh hasil belajar biologi siswa pada materi pokok sistem ekskresi di kelas XI MIA SMA Negeri 16 Medan Tahun Pembelajaran 2016/2017, siswa tersebut memiliki pengetahuan dan tingkat kenalaran yang cukup baik sehingga mampu menjawab soal-soal yang telah dipersiapkan, dengan persentase hasil belajar yang diperoleh (59\%) dengan jumlah 89 siswa memperoleh hasil belajar dengan kategori cukup. 
Dalam hal ini motivasi belajar siswa yang tergolong kategori cukup memberikan gambaran yang baik dengan hasil belajarnya yang termasuk kategori cukup.

Motivasi memiliki peranan penting dalam belajar. Orang yang memiliki besar motivasi akan giat berusaha, tampak gigih dan tidak mudah menyerah. Seseorang akan berhasil jika pada dirinya ada keinginan ataupun dorongan untuk belajar karena motivasi dapat menentukan baiktidaknya seseorang dalam mencapai tujuan. Sehingga semakin besar motivasi seseorang akan semakin besar juga kesuksesan belajarnya (Uno, 2013).

Sardiman (2014) menyatakan "seseorang akan berhasil belajar, kalau pada dirinya sendiri ada keinginan untuk belajar". Berdasarkan pengamatan peneliti, motivasi adalah dasar dari kegiatan pembelajaran siswa dan guru, selama melaksanakan penelitian beberapa siswa menunjukkan motivasinya ditandai dengan aktivitas belajar, dan hasil belajar yang diperoleh siswa cukup indikator KKM $(\geq 70)$. Guru harus menumbuhkan motivasi siswa dan menyambut motivasi belajar yang ditujukan siswa.

Penelitian Sari (2013) menyimpulkan bahwa motivasi belajar mempunyai hubungan yang signifikan dengan hasil belajar siswa. Berdasarkan kontribusi motivasi terhadap hasil belajar siswa di SMP Negeri 1 Kranggaan Kecamatan Kranggaan Kabupaten Temanggung pada semester 1 tahun pembelajaran $2012 / 2013$, yaitu sebesar $56,6 \%$, dan Danar (2012) membuktikan bahwa terdapat hubungan positif dan signifikan antara motifasi belajar dengan hasil belajar siswa. Besar kontribusi motivasi dengan hasil belajar siswa kelas X SMK MA'ARIF WATES yaitu sebesar 59,3\%. Sedangkan motivasi belajar siswa di SMA Negeri 16 Medan memberi kontribusi lebuh rendah yaitu sebesar $22 \%$ terhadap hasil belajar siswa, dapat disebabkan karena faktor lain, selain motivasi belajar lebih banyak berpengaruh misalnya: faktor internal (integensi, minat, bakat, perhatian, bakat, keadaan fisik, dan sikap) dan faktor eksternal (faktor lingkungan keluarga, sekolah dan masyarakat).

Hasil belajar dipengaruhi oleh faktor internal dan juga eksternal. Faktor internal yang mempengaruhi hasil belajar yaitu semua faktor yang berasal dari diri siswa itu sendiri antara lain faktor fisik dan faktor psikis. Faktor fisik yaitu faktor kesehatan jasmani siswa ketika belajar dan psikis yaitu kecerdasan, motivasi, gaya belajar, pemahaman siswa. Sabar (2006) menyatakan hasil belajar biologi dipengaruhi oleh keterampilan sains, dan menegaskan kecerdasan matematis logis berpengaruh terhadap hasil belajar biologi siswa,
Afnidar (2012) menyatakan bahwa pemahaman siswa yang kurang akan mengakibatkan rendahnya hasil belajar. Suviana (2012); Sanjaya (2010); Aritonang (2008) menyatakan bahwa hasil belajar dipengaruhi motivasi belajar siswa baik dari faktor internal maupun eksternalnya. Lumban Gaol, R (2014) juga menyatakan bahwa hasil belajar dipengaruhi oleh kemampuan numerik, keterampilan proses sains dan pemahaman konsep yang merupakan faktor internal hasil belajar. Dengan hasil korelasi yang positif ini dapat dinyatakan bahwa semakin tinggi motivasi belajar siswa maka akan semakin tinggi pula hasil belajar siswa. Begitupula sebaliknya semakin rendah motivasi belajar siswa maka akan diikuti hasil belajar yang rendah pula dan lingkungan sekolah).

Berdasarkan hasil pemberian angket motivasi belajar diketahui bahwa motivasi intrinsik lebih menonjol daripada motivasi ekstrinsik. Motivasi intrinsik yang menonjol adalah citacita/aspirasi pembelajaran, aktualisasi diri, minat, dorongan menyenangkan hati orang lain, memperoleh pengetahuan dan hasrat dalam diri untuk belajar khususnya pada materi sistem ekskresi pada manusia ini. Sedangkan pada motivasi ekstrinsik yaitu kondisi lingkungan belajar tergolong baik, hanya bisa saja respon guru memberi motivasi yaitu cara memberi angka (nilai), pujian, menciptakan persaingan yang sehat didalam kelas tergolong rendah sehingga menimbulkan persepsi dalam diri siswa bahwa belajar biologi merupakan pelajaran yang membosankan dan juga hanya pelajaran hafalan saja.

Temuan ini memberikan masukan pada pihak sekolah agar berupaya lebih memperlengkapi sarana dan prasarana disekolah dan bagi para guru agar lebih meningkatkan upaya dalam membelajarkan siswa. Meskipun demikian hasil ini bukanlah mencerminkan kesimpulan yang sempurna karena peneliti menyadari kemungkinan adanya kelemahan-kelemahan dalam penelitian ini, diantaranya adalah angket motivasi belajar belum tentu mencerminkan motivasi belajar siswa yang sesungguhnya, sebab ada kemungkinan siswa mengisi angket dengan nilai yang baik-baik saja jadi angket yang disusun belum dapat mendeskripsikan secara sempurna hal yang sesungguhnya.

\section{KESIMPULAN}

Hasil penelitian menunjukkan bahwa Terdapat hubungan yang signifikan antara motivasi belajar dengan hasil belajar siswa pada materi pokok sistem ekskresi di kelas XI MIA SMA Negeri 16 Medan Tahun Pembelajaran 2016/2017. Motivasi belajar siswa memberikan kontribusi sebesar $22 \%$ terhadap hasil belajar siswa pada materi pokok 


\section{UCAPAN TERIMA KASIH}

Terima kasih terkhusus $\mathrm{Ibu} \mathrm{Hj}$. Fauziah Hasibuan, S.Pd, M.Sisebagai kepala sekolah dan seluruh siswa kelas XI MIA di SMA Negeri 16 Medan membantu selama penelitian berlangsung.

\section{DAFTAR PUSTAKA}

Afnizar, D. (2009). Hubungan Motivasi Dengan Hasil Belajar Siswa pada Mata Pelajaran Biologi di MAN Kualuh Selatan Labuhan Batu Tahun Pembelajaran 2008/2009. Medan : UNIMED.

Afnidar. (2012). Pengaruh Strategi Pembelajaran Inkuiri dan Kepercayaan Diri terhadap Hasil Belajar dan Keterampilan Proses Sains Biologi Siswa pada Topik Pencemaran Lingkungan di SMA Negeri 1 Mutiara, Medan : Tesis Pascasarjana Unimed.

Arikunto, S. (2010). Prosedur Penelitian Suatu Pendekatan Praktik. Jakarta: Rhineka Cipta.

Aritonang, K.E. (2008). Minat dan Motivasi dalam Meningkatkan Hasil Belajar Siswa. Jakarta. Jurnal Pendidikan Penabur, Vol 10 (1) : 1-7.

Danar, V. F. (2012). Hubungan Motivasi Belajar Intrinsik dan Ekstrinsik Siswa dengan Prestasi Belajar Siswa Kelas X Kompetensi Keahlian Teknik Audio Video SMK MA'ARIF 1 WATES. Jurnal Pendidikan dan Pembelajaran. Vol 2.

Lumban Gaol, R. (2014). Kaitan antara Kemampuan Numerik, Keterampilan Proses Sains dan Pemahaman Konsep terhadap Hasil Belajar dan Sikap Biologi. Medan : Tesis Pascasarjana Unimed.

Jihad dan Haris. (2012). Evaluasi Pembelajaran. Jakarta: Multi Persindo.

Sardiman, A.M. (2010).Interaksi dan Motivasi Belajar Mengajar. Jakarta: Raja Grafindo Persada.

Sabar. (2008). Peningkatan Thingking Skill melalui pembelajaran IPA Berbasis Kontruktisme di Sekolah Alam. Jurnal Penelitian dan Evaluasi Pendidikan. 1(1): 1-6.

Sanjaya. (2010). Kurikulum Pembelajaran Edisi Pertama Cetakan Ke-3. Jakarta: Kencana.

Sari, W. (2013). Hubungan Motivasi Belajar dengan Hasil belajar PKn Pada Siswa Kelas VII SMP Negeri 1 Kranggan Temanggung. Jurnal Pendidikan dan Pengajaran. Vol 15.

Slameto. (2013).Belajar dan faktor-faktor yang Mempengaruhinya. Jakarta:Rineka Cipta.

Suviana. (2012).Hubungan Kausal antara Motivasi Internal dan Kesiapan Belajar dengan Hasil belajar Kognitif pada Mata Pelajaran Biologi di SMA Negeri 1 Cawas Tahun Pembelajaran 